\title{
The Mediating Effect of Political Intensity on Attitude, Farming Practices, Sources of Funds on Ghana Cocoa Farmers' Financial Sustainability
}

\author{
Williams Kwasi Peprah, Ph.D. CSSB, F.cfia \\ Valley View University, Accra, Ghana, School of Business
}

\begin{abstract}
Cocoa farmers now need financial sustainability in doing their businesses. To ensure their financial sustainability, they must have the right attitude and incorporate appropriate farming practices and funding. This study concentrates on financial sustainability in that it is related to the availability of agricultural funding and the impact on society for present and future generations to ensure a healthy livelihood for the cocoa farmer.This study is a quantitative study and a correlational research design which used mediation approach to predict and explain the intervening role of political intensity in determining the financial sustainability Ghana's cocoa farmers based on attitude, practices and sources of funds. The study employed 980 cocoa farmers across the six cocoa growing regions of Ghana to conveniently answer self-contructed research questions with interval validity based on Cronbach Alpha of farmers' attitude 0.84, farming practices 0.84 , sources of funds 0.7 , and political intensity 0.955 , Financial Sustainbility 0.86 . The statistical treatment for the prediction was based on regression and AMOS $23 \mathrm{v}$ was used to determine the mediation effect.The study resulted that the predictors of cocoa farmers' financial sustainability are political intensity, farmers' attitude and farming practices. Political intensity partially mediates farmers' attitude and financial sustainability and fully mediate farming practices and sources of funds to financial sustainability. The study recommends that the various approaches used in finding financial sustainability must be synchronized as this study showed a covariate of all the predictors. The disjointed approach in seeking financial sustainability for the cocoa farmer will fail.
\end{abstract}

Keywords: Attitude, Farmers' Practices, Sources of Funds, Political Intensity, Financial Sustainability

DOI: $10.7176 /$ RJFA/11-10-15

Publication date:May $31^{\text {st }} 2020$

\section{Introduction}

Cocoa farmers now need financial sustainability in doing their businesses. To ensure their financial sustainability, they must have the right attitude and incorporate appropriate farming practices and funding. This study concentrates on financial sustainability in that it is related to the availability of agricultural funding and the impact on society for present and future generations to ensure a healthy livelihood for the cocoa farmer.

World Bank (2016) reported that $75 \%$ of the world's population is poor, living in rural areas and under US\$ 1. These rural dwellers are not financially stable. In Africa, an average of 43 percent of farmers lives in this situation. It is proclaimed that $50 \%$ of the agricultural labor force in Ghana is not financially sustained and lives under US\$ 1 a day.

In Ghana's standard of living in poverty and inequality report by the United Nations International Children's Emergency Fund (UNICEF), 10\% of the people lived in extreme poverty (Cooke, Hague, \& Mackay, 2016). Their research showed that, relative to urban and rural poverty, rural poverty is four times the urban poverty rate. The rural world is made up of people who are predominantly farmers.

World Poverty Clock statistics affirm that about $10 \%$ of Ghana's population is living below the global poverty line of \$1.9 per day (Larnyoh, 2018). Cocoa Initiative (2017) estimated that Ghana's daily per capita income for cocoa farmers is approximately $\$ 0.40-\$ 0.45$, which is well below the daily poverty line and is therefore not financially sustained.

This study considers the role of the attitude of the cocoa farmer, their farming practices, and the availability of sources of funds will contribute to finding financial sustainability for the cocoa farmer in Ghana when intervene by the current political intensity. Until lately, when Peprah (2018), and Peprah, Carpizo, and Asuah-Duodu, (2019) study on the impact of sustainable leaders and funding sources and the profile difference on Ghanaian cocoa farmers respectively, not much study has focused on the cocoa farmers' financial sustainability. Therefore, this research fills the gap in knowledge.

It has recently been noted that cocoa farmers cut their trees and replace them with rubber plantations because cocoa farming is not financially sustainable (Gakpo, 2018). It is this crux issue that instigated this study. Therefore, the study pursues to answer the following research questions:

1. Which among the following variables predict financial sustainability:

a. Attitude

b. Farming Practices 
c. Sources of Funds

d. Political Intensity

2. Does political intensity mediate the following relationship:
a. Farmer's attitude and financial sustainability
b. Farming Practices and financial sustainability
c. Sources of funds and financial sustainability

\section{Attitude and Financial Sustainability}

Hira (2016), determined the relationship between financial sustainability and behavior in the conceptual study of financial sustainability and personal finance education. Financial sustainability has been defined by Hira (2016), as the management of limited resources to meet current needs and to have a plan for the long-term goals and needs. Behavior which is an attitudinal(Orderud \& Vogt 2016) element in financial sustainability, is employing the attitudinal strategies to efficiently reduce the dependence on debt to manage limited financial resources, to increase emergency preparedness, and to have a big plan and long-term financial goals.

These attitudes which have been assessed in objective and subjective measurement must sustain the farmer to provide financial security. Objective elements measure the farmers' net worth that is the outcome of savings and investment as related to their source of funding, and debt to income ratio. These are the indicators for measuring the farmers' long-term financial sustainability as represented in financial viability, financial reliance and financial self-sufficiency (Hira, 2012). The subjective attitudinal measurement elements consist of happiness, quality of life and satisfaction (Hira, 2016). In this research study, these factors are discussed under financial outreach and financial impact, which are part of the doctrines of financial sustainability.

\section{Farming Practices and Financial Sustainability}

With the debates on which of the sustainable agricultural practice provides sustainable financial in viability and profitability for now and the future, empirical researchers have obtained mixed results from various products in different countries. In 2018, a study by Berg, Maneas, and Engstrom in Greece showed that Organic farming is profitable than conventional farming in olive farming. Another study by Klonsky and Greene (2005) provided mixed results for both farming practices. Rodale Institute (2007), in celebrating their 30 years of trail of comparison on financial performance of organic farming to conventional farming since 1981 on corn and soybeans, concluded that organic farming practices are more profitable than conventional farming. The economic analysis from 2008 to 2010 showed a profit of $\$ 190$ to $\$ 558$ per acre a year for organic farming and conventional farming respectively, in the USA.

In Europe, a study by Greer, Kaye-Blake, Zellman, and Parsonson-Ensor (2008) found out that conventional farms are relatively profitable than organic farms. It is collaborated by results on Italian Olive-grown farms, which showed high gross production net margin, net profit, and cost than organic farming (Madau, 2007).

Also by Addae-Boadu (2014) that Ghana organic farming is sustainably higher than conventional farming in cocoa farms. Bandanaa, Susana, and Asante (2016) have collaborated that regarding sustainable livelihood outcomes for food security, income, vulnerability, and well-being, organic farming practice is better as compared to conventional farming.

\section{Sources of Funds and Financial Sustainability}

The interconnection of sources of funds and financial sustainability is drawn on the line of meeting the Sustainable Development Goals (SDGs). According to Schmidt-Traub, and Sachs (2015), finance gives credibility to the agreement on SDGs because meeting the SDGs will end poverty which in turn make the farmer financially sustainable. The United Nation (UN) initiated this project to transform the world by 2030 helping alleviate poverty, and by improving life and the environment. It is currently based on seventeen goals. There are various bodies under the UN and the World Bank working towards this agenda. There have been various models of sources of funds and discussions on meeting the SDGs to create such sustainability to effect financial sustainability.

Sustainable funding (2018) has given the following classifications on sources of funds that give financial sustainability. Sustainable financing has multiple streams or a variety of sources to fund a venture for now and the future. These sources of funds include donation, grant, trade revenue, debt financing, social investment and venture philanthropy. Donations are non-returnable monies. Grants are non-returnable money given for a particular project which can be for capital expenditure or for meeting an on-going expense. Trading sources of funds are revenue from sales. Debt finance funds one with interest-bearing on return to the financier. Social investment is fund that expects some returns on the return of their funds and also create a social impact. Venture philanthropy is the source of funds from the venture capitalist who expects to make a social return but not financial returns.

The United Nations (2014), based on the Millennium Declaration in 2000, has been involved in identifying sustainable funding for financial sustainability and poverty eradication in the world. The UN recognizes the risk and vulnerability in environmental degradation, climate changes, and international finance risk. As a result, the 
UN has indicated the following sustainable funding sources for financial sustainability: domestic public finance, domestic private financing, international private finance and blended finance.

The domestic public finance is a governmental approach in raising funds through tax reforms, prevention of tax evasion and illicit flows. According to Peprah and Osei-Bonsu (2017) both tax evasion and avoidance are unethical, illegal and unbiblical which will have greater impact on financial sustainability. Domestic private finance is inclusive finance for households through capital market activities; this requires the involvement of all actors in the financial market namely, cooperative, banks, microfinance, savings and loans, and investment and assets firms. International private finance provides global funds. Its funds are a long-term investment in nature for sustainability. Lastly, the UN mentioned the blended finance which is a combination of public and private resource need to aid financial sustainability.

The World Bank (2015) notes that financial sustainability is based on what they call patient capital. It is the quest of the World Bank to help in the achievements of the SDGs set by the UN. As a result, they seek sources of funds that will support sustainability. In 2015, the World Bank paneled financial experts to deliberate on this topic. It came to light that there should be a change in the current mindset in order to get to financial sustainability. A key source of funding for financial sustainability was patient capital.

Patient capital funds for long-term investments assist sustainability and inclusive growth. It aims to increase the life-cycle instrument for households. The UN (2014) discussed where to place patient capital in the current financial modeling. They concluded that it should be in the middle of traditional venture capital which motive is maximizing financial returns and traditional philanthropy whose aim is maximizing social impact. The results showed that patient capital, which will support financial sustainability must be set silently above zero percent. It meant that patient capital, which is a blend of social and financial returns had to support long-term social impact for financial sustainability. The returns generated by patient capital will be reinvested to alleviate poverty and provide financial sustainability (Deeg, Hardie, \& Maxfield, 2016).

\section{Political intensity}

The political intensity in this research is discussed based on the government interventions and the ability of the cocoa farmer to make inquiries. Agriculture has been the main backbone of Ghana's economy during the colonial times and until 2006 rebasing from the gross domestic product when the service industry took over. The dominant product that caused this influence has been cocoa farming. As reported by Alence (1990), cocoa farmers have actively engaged in the political intensity of the then Gold Coast now Ghana. These farmers caused a commercial stalemate between the years 1937-1938 when they noticed that they were cheated by the European buyers on the selling price. Some of them were then appointed into the decision making roles within their community to influence the political system.

This system has not changed even until now. Cocoa farming contributes to Ghana gross domestic product by $25 \%$ (Ayanful, 2016). As a result, the government seeing the influential role of cocoa farming in Ghana established the Ghana Cocoa Board in 1947 to hold all political and economic administration of the cocoa industry. Through this organized board, the cocoa farmer has been engaged in the political intensity of the country. The Ghana Cocoa Board is the political entity mandated by law to fix the cocoa price and engage the farmers. The cocoa farmers association in Ghana has a representative in the board, and the representative is the mouthpiece in governance. This has limited the mass participation of cocoa farmers in the administration of their affairs. All government intervention programs and developments are channeled through the Ghana Cocoa Board. The cocoa farmers at each level have an elected leader who communicates their grievances to the government through the Ghana Cocoa Board

Let it be called cocoa political intensity in Ghana. This phenomenon is one of the strong cards used by all the political parties in their election campaign. According to Arthur (2018), as also noted by International Food Policy Research Institute, the politicization of the cocoa industry will cause it to dip because the politicians have exploited the gains of the industry instead of seeking the interest of the farmer.

In a recent outburst, Dauda (2018) lamented that the current government has failed to deliver its promise to increase the price of cocoa by 70\%. In a study by Anang, Mensah and Asamoah (2013) to assess the impact of government free cocoa spray program in Wassa Amenfi West District $14.2 \%$ of the respondents indicated that they have not benefited from the program since 2001 and $68.3 \%$ were dissatisfied with the spraying. It is because the spraying did not follow the right approach. Also, some farming communities have benefited from cocoa road projects. However, as reported by Allotey and Opoku (2017) on the parliamentary debate, a minority spokesperson on agriculture said that the current government has neglected the previous government projects on cocoa roads, spraying exercise, and in the distribution of free fertilizes to the cocoa farmer. These measures were what the government has embarked upon to improve the lives of the cocoa farmer indirectly.

The Ghana government has no policy on which type of farming practices the farmer should engage in. As a result, they distribute fertilizer freely to the cocoa farmers for both the organic and conventional. What the government is interested in is achieving its targeted yield (COCOBOD, 2010). 


\section{Method}

This is a quantitative study and a correlational research design. It applied the conditional indirect effect to help in describing and understating the conditional nature of transmitting effects of political intensity on the relationship between attitude, practices, and sources of funds (Hayes, 2009). Ghana's cocoa farmers were estimated at 800,000 according to the official website of Ghana COCOBOD. This study surveyed 1,000 cocoa farmers conveniently as respondents from Ghana's six cocoa-growing regions, outliers of which were 20 respondents. Therefore, the research used by 980 cocoa farmers respondents. The respondents were given the self-constructed questionnaires. The internal consistency of the variables were measured with Chronbach alpha and they resulted as farmers' attitude 0.84 , farming practices 0.84 , sources of funds 0.7 , and political intensity 0.955 , Financial Sustainbility 0.86 . Ethical consideration was applied in the data collection.

The magnitude of the strength of the relationship is determined and interpreted on the absolute values of Cohen (1988) where $r=.10$ to. 29 is small/low, $r=.30$ to. 49 is medium/ moderate, and $r=.50$ to 1.0 is large/high. The statistical treatment for the prediction was based on regression and IBM SPSS AMOS 23v was used to determine the mediation effect.

The null hyupothesis for the study is as shown below:

1. None of following variables predict financial sustainability:
a. Attitude
b. Farming Practices
c. Sources of Funds
d. Political Intensity

2. Political Intensity does not mediate the following relationship:
a. Farmer's attitude and financial sustainability
b. Farming Practices and financial sustainability
c. Sources of funds and financial sustainability

\section{Results and Discussion}

The gender distribution of the respondent consisted of 658 men (67\%) and 322 women (33\%). Their age varies from 15-35 years of age $236(24 \%), 36-60$ years of age $712(73 \%)$ and 32 years of age $61-65(3 \%)$.

\section{Predictors of Financial Sustainability}

Linear regression analysis approach was used to assess the ability of the four independent variables to predict financial sustainability. After going through the process, the total variance explained by the model as a whole was $30.2 \%, \mathrm{~F}(6,976)=140.693, \mathrm{p}<.000$. From the predictive results, the explained variables on financial sustainability are political intensity $23.8 \%$, Famers' Attitude $5.7 \%$ and Farming Practices $0.7 \%$. Sources of funds was excluded from the predictors as it was not significant $p=.513$. However, there are $69.8 \%$ variables which were not considered in this study but can explain financial sustainability for the cocoa farmer in Ghana. The proposed applied model based on the unstansardazied beta for this study is FSB $=\mathbf{2 . 1 1 3}-\mathbf{. 0 7 1 P I}+\mathbf{3 4 3 F A}-\mathbf{. 0 6 1}$ FP.

Table 2

Predictors of Financial Sustainability

\begin{tabular}{lllllll}
\hline & R Square Change & \multicolumn{1}{c}{ B } & Std. Error & Beta & \multicolumn{1}{c}{ t } & Sig. \\
\hline Constant & & 2.113 & 0.158 & & 13.36 & .000 \\
Political Intensity & 0.238 & -0.071 & 0.013 & -0.232 & -5.457 & .000 \\
Farmers' Attitude & 0.057 & 0.343 & 0.038 & 0.296 & 9.016 & .000 \\
Farming Practices & 0.007 & -0.061 & 0.019 & -0.119 & -3.153 & 0.002 \\
\hline & $\mathbf{R = . 5 4 9}$ & $\mathbf{R 2}=\mathbf{. 3 0 2}$ & $\mathbf{F = 1 4 0 . 9 6}$ & $\mathbf{p}=\mathbf{. 0 0 0}$ \\
\hline Excluded Predictor & & & & & \\
\hline Sources of Funds & & -0.023 & & & -0.655 & 0.513 \\
\hline
\end{tabular}

\section{Mediation by Political Intensity}

According to Baron and Kenny (1986), mediation is simply establishing if there is a causal relationship between the independent variable and the dependent variable through an intervening variable. The role of the mediator is to give an account of the relationship or explain why and how an effect occurs. This study looked into the mediating effect of political intensity on the relationship of farmer's attitude and financial sustainability, farming practices and financial sustainability, sources of funds and financial sustainability. An initial path regression model of the relationships showed that sources of funds related to financial sustainability was not statistically significant $\mathrm{p}=.413$ as showed in Table 3 . 
Table 3

Initial Path Regression Model for Political Intensity as a Mediator

\begin{tabular}{lllrrrrll}
\hline- & & & Estimate & S.E. & C.R. & Pabel & VI \\
\hline cenPI & $<---$ & cenSF & 0.931 & 0.069 & 13.53 & $* * *$ & par_1 & S \\
cenPI & $<---$ & cenFP & 0.717 & 0.039 & 18.556 & $* * *$ & par_3 & S \\
cenPI & $<---$ & cenFA & -1.232 & 0.086 & -14.394 & $* * *$ & par_4 & S \\
cenFSB & $<---$ & cenFA & 0.354 & 0.042 & 8.367 & $* * *$ & par_2 & S \\
cenFSB & $<---$ & cenPI & -0.069 & 0.017 & -4.075 & $* * *$ & par_5 & S \\
cenFSB & $<---$ & cenFP & -0.052 & 0.021 & -2.542 & 0.011 & par_6 & S \\
cenFSB & $<---$ & cenSF & -0.027 & 0.034 & -0.818 & 0.413 & par_7 & NS \\
\hline
\end{tabular}

$\mathrm{S}=$ Significant, NS=Not Significant

With the help of the modification indices, farmers 'attitude, farming practices and sources of funds were covariate. In the determination of a model fit for political intensity to be able to explain the relationship, the study revealed that the mediating effect of political intensity on the relationship between farmers' attitude and financial sustainability was significantly partial and small (Estimate $=0.119, \mathrm{p}=0.002)$. However, the mediating role of political intensity between the relationship of farming practices and financial sustainability (Estimate $=-0.069, \mathrm{p}=$ 0.001 ) and sources of funds and financial sustainability (Estimate $=-0.09, p=0.001$ ) were significantly small full mediation. This means whereas, farmers' attitude can directly, and indirectly impact on cocoa farmers' financial sustainability, farming practices and sources of funds will rely on political intensity to impact on cocoa farmers' financial sustainability.

Table 4

Final Regression Model of Political Intensity as a Mediator

\begin{tabular}{|c|c|c|c|c|c|c|c|c|}
\hline & & & Estimate & S.E. & C.R. & $\mathrm{P}$ & Label & VI \\
\hline cenPI & $<---$ & cenSF & 0.931 & 0.08 & 11.58 & $* * *$ & par_1 & $S$ \\
\hline cenPI & $<---$ & cenFP & 0.717 & 0.047 & 15.141 & $* * *$ & par_3 & S \\
\hline cenPI & $<---$ & cenFA & -1.232 & 0.093 & -13.204 & $* * *$ & par_4 & S \\
\hline cenFSB & $<---$ & cenFA & 0.349 & 0.045 & 7.728 & $* * *$ & par_2 & S \\
\hline cenFSB & $<---$ & cenPI & -0.096 & 0.012 & -8.097 & $* * *$ & par_5 & S \\
\hline
\end{tabular}

$\mathrm{S}=$ Significant, NS=Not Significant

Table 5

Good Fit Results for Political Intensity as a Mediation

\begin{tabular}{lrl}
\hline Fit Measure & Results & Verbal Interpretation \\
\hline Chi-square & 2.991 & Acceptable \\
p-value & 0.5 & Good Fit \\
RMSEA & 0.055 & Good Fit \\
CFI & 0.996 & Good Fit \\
GFI & 0.997 & Good Fit \\
\hline
\end{tabular}

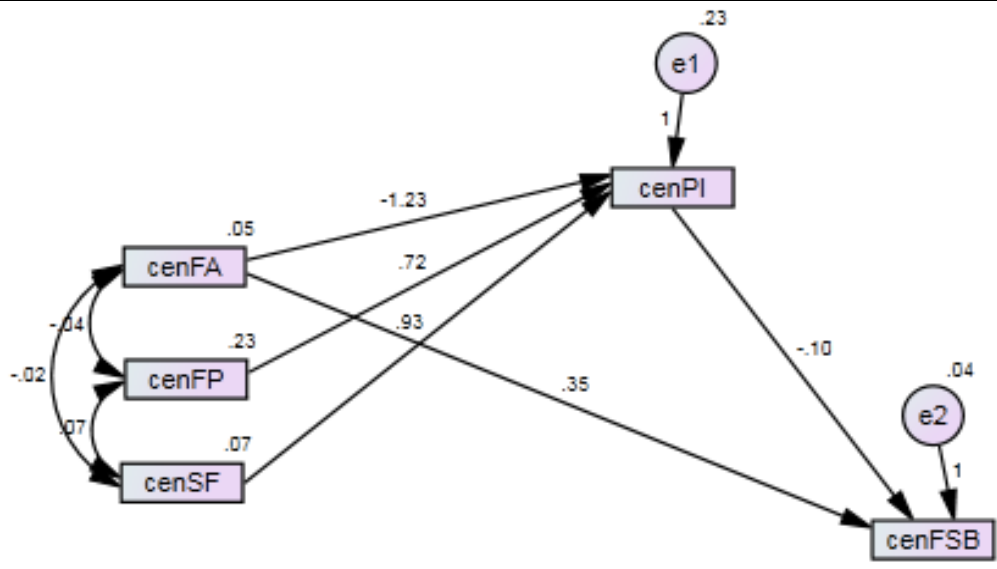

ChiSquare $=5.981 ; d f=2 ; p=.050$

;RMSEA=.055; GFI=.996; CFI=.997

; Standardized RMR $=.0323$

Figure 1. Political Intensity - Mediation Model 
In inference, the study rejected the null hypothesis that political intensity does not mediate the relationship between farmers' attitude, farming practices, and financial sustainability. The revelation is that political intensity role accounts for cocoa farmers' financial sustainability. An important aspect of the cocoa industry in Ghana has been the impact of politics. As this study confirms the mediating effect of political intensity, these important results is supported by Alence (1990) upon the engagement of cocoa farmers into politics and Arthur (2018) claim that there is politicization in cocoa farming which affects the cocoa farmers' financial sustainability.

Table 6

Summary Table for Political Intensity as a Mediator and Magnitude of Effect Size

\begin{tabular}{llllrrrrrl}
\hline IV & Med & DV & Type & Estimate & Lower & Upper & p-value & IV & Magnitude \\
\hline FA & PI & FSB & Partial & 0.119 & 0.091 & 0.152 & 0.002 & S & Small \\
FP & PI & FSB & Full & -0.069 & -0.089 & -0.053 & 0.001 & S & Small \\
SF & PI & FSB & Full & -0.09 & -0.119 & -0.066 & 0.001 & S & Small \\
\hline
\end{tabular}

$\mathrm{IV}=$ Independent Variable, Med=Mediator, DV $=$ Dependent Variable, Type $=$ Type of Mediation

\section{Conclusion}

The study concludes that the predictors of cocoa farmers' financial sustainability are political intensity, farmers' attitude and farming practices. Political intensity partially mediates farmers' attitude and financial sustainability and fully mediate farming practices and sources of funds to financial sustainability. The study recommends that the various approaches used in finding financial sustainability must be synchronized as this study showed a covariate of all the predictors. The disjointed approach is seeking financial sustainability that will fail. A more structured and systematic approach is needed in finding financial sustainability for the cocoa farmer.

The study noted that there are $69.8 \%$ predictors which were not included in the study to predict financial sustainability for the cocoa farmer. It is recommended that future researchers investigate into them to enhance the literature and solutions for financial sustainability

\section{Reference}

Addae-Boadu, S. (2014). The cocoa certification program and its effect on sustainable cocoa production in Ghana: A case study in Upper Denkyira West District. A Thesis submitted for Master of Science Environmental Science at Kwame Nkrumah University of Science and Technology. Retrieved from: http://dspace.knust.edu.gh/bitstream/123456789/6966/1/SAMUEL\%20ADDAE-BOADU.pdf.

Alence, R. (1990). The 1937-1938 gold coast cocoa crisis: The political economy of commercial stalemate. African Economic History, 19, 77-104. DOI: 10.2307/3601893.

Allotey, G.A \& Opoku, D.M. (2017). Gov't has neglected cocoa farmers - Minority. Retrieved form: http://citifmonline.com/2017/10/23/govt-has-neglected-cocoa-farmers-minority/.

Anang, B.T., Mensah, F. \& Asamoah, A. (2013). Farmers' Assessment of the Government Spraying Program in Ghana. Journal of Economics and Sustainable Development, 4(7), 92-99.

Arthur, A. (2018). Political interference threatens future of Ghana's cocoa. Retrieved from: http://citifmonline.com/2018/02/24/political-interference-threatens-future-ghanas-cocoa/

Ayanful, R. (2016). Cocoa said to contribute $25 \%$ to Ghana's GDP. Retrieved from: https:/www.newsghana.com.gh/cocoa-said-to-contribute-25-to-ghanas-gdp/.

Bandanaa, J., Susana, I., \& Asante, I. (2016).Cocoa farming households in Ghana consider organic practices as climate smart and livelihood enhancer. Agriculture and Food Security. DOI: 10.1186/s40066-016-0077-1.

Baron, R. M., \& Kenny, D. A. (1986). The moderator-mediator variable distinction in social psychological research: Conceptual, strategic and statistical considerations. Journal of Personality and Social Psychology, $51,1173-1182$

Berg, H., Maneas, G. \& Engstrom, A.S. (20 A Comparison between Organic and Conventional Olive Farming in Messenia, Greece. Horticulturae, 4, 15; doi:10.3390/horticulturae4030015.

Cocoa Initiative (2017). Cocoa farmers in Ghana experience poverty and economic vulnerability. Retrieved from: https://cocoainitiative.org/news-media-post/cocoa-farmers-in-ghana-experience-poverty-and-economicvulnerability/.

COCOBOD. 2010. Ghana Cocoa Sector Development Strategy II.

Cohen, J. W. (1988). Statistical power analysis for the behavioral sciences (2nd ed.). Hillsdale, NJ: Lawrence Erlbaum Associates.

Cooke, E. Hague, S. \& Makay, A. (2016). The Ghana poverty and inequality report. Retrieved from: https://www.unicef.org/ghana/Ghana_Poverty_and_Inequality_Analysis_FINAL_Match_2016(1).pdf.

Deeg, I., Hardie, I. \& Maxfield, S. (2016). What is patient capital, and where does it exist? Socio-Economic Review, 14(4), 615-625. https://doi.org/10.1093/ser/mww030.

Duauda, C. (2018). NPP government has disappointed cocoa farmers. Retrieved from: 
https://www.ghanaweb.com/GhanaHomePage/political intensity/NPP-government-has-disappointed-cocoafarmers-Collins-Dauda-614492.

Gakpo, J.O. (2018). Rubber plantations are displacing Ghana's small cocoa farms. Retrieved from: https://allianceforscience.cornell.edu/blog/2018/03/rubber-plantations-displacing-ghanas-small-cocoafarms/.

Greer, G.,Kaye-Blake,W., Zellman, E., \& Parsonson-Ensor, C. (2008).Comparison of the financial performance of organic and conventional farms. Journal of Organic Systems, 3, 2.

Hayes, A.F. (2009). Beyond Baron and Kelly: Statistical mediation analysis in the new millennium. Communication Monograph, 76, 408-420. Doi: 10.1080/03637750903310361.

Hira, T. (2012). Financial attitudes, beliefs and behaviors: Difference by age. Journal of Consumer Studies and Home Economics, 21, 271-290.

Hira, T.K. (2016). Finance sustainability and personal finance education. Switzerland: Springer International Publication. DOI 10.1007/978-3-319-28887-1 29.

Klonsky, K., \& Greene, C. (2005).Widespread adoption of organic agriculture in the u.s: are market-driven policies enough? Paper presented at American Agricultural Economic Association Annual Meeting, Providence, Rbiode Island.

Larnyoh, M.T. (2018). 2.8 millio Ghanaians are living in extreme poverty report. Retrieved from: https://www.pulse.com.gh/ece-frontpage/world-poverty-clock-28-million-ghanaians-are-living-in-extremepoverty-report/7f1 eemx.

Madau, F. C.F. (2007). Organic \& conventional farming: a comparison analysis through the Italian FADN. Retrieved from: www.orgprints.org/14139/1cisilino-Madau.pdf.

Orderud, G.I. \& Vogt, R.D. (2016). Environmental values and attitudes among farmers in China - a case study in the watershed of Yuqiao reservoir of Tianjin Municipality, China. The International Journal of Environmental Studies. 73(6): 917-938, doi: 10.1080/00207233.2016.1220699.

Peprah, W., Asuah-Duodu, E., \& Carpizo, R. (2019). The Difference Between Ghana Cocoa Farmers' Personal Profile on their Financial Sustainability. Abstract Proceedings International Scholars Conference, 7(1), 10541066. https://doi.org/10.35974/isc.v7i1.953.

Peprah, W.K. \& Osei-Bonsu, R. (2017). Theological and ethical perspective of tax avoidance. International Journal of Innovative Research and Development, 6(10), 90-93. DOI No. : 10.24940/ijird/2017/v6/i10/OCT17083.

Rodale Institute (2007). The farming systems trail celebrating 30 years. Retrieved from: http://biowad.nl/upload/BWD-artikelen/Rodale\%20Farming\%20Systems\%20Trial\%2030\%20years.pdf.

Schmidt-Traub, G., \& Sachs, J. D. (2015). Financing Sustainable Development: Implementing the SDGs through Effective Investment.

Sustainability: A Key to Transforming Agricultural Financing. A paper presented at the 4th Research Conference on Sustainable Development Goals: Transforming Africa at the Adventist University of Africa, Nairobi, 13 ${ }^{\text {th }}$ - $15^{\text {th }}$ September, 2018.

Sustainable funding. The Sustainable Funding Mix. (September 26, 2018). Retrieved from: http://www.valonline.org.uk/book/export/html/237.

United Nations (2014). Sustainable Development Financing. Retrieved from: http://www.un.org/esa/ffd/documents/ICESDF.pdf .

World Bank (2015). Financing for Sustainable Development: From Billions to Trillions - What Will it Take? Retrieved from: 1424899383242/DFF2015SummaryReport.pdf.

World Bank (2016). Agriculture and poverty reduction. Retrieved from: http://web.worldbank.org/wbsite/external/extdec/extresearch/exTWDRS/0, contentMDK:21501332 pageP K:478093 piPK:477627 theSitePK:477624,00.html 